\title{
DEVELOPMENT OF A WEB-BASED CBS ORGANIZATION SYSTEM FOR MEGA-PROJECTS
}

\author{
Chang Teak Hyun*, Run Zhi Jin, Myung Jin Son, Beom Suk Park, and You Sang Yoon \\ Department of Architecture Engineering, University of Seoul, Seoul, Korea \\ *Corresponding author (cthyun@uos.ac.kr)
}

\begin{abstract}
The construction business is gradually progressing towards the implementation of large-scale mega-projects for the creation of a synergy effect within limited grounds. However, various problems are manifesting, such as increased project costs, delays in the construction duration, and conflicts between stockholders. Thus, this study aimed to develop a web-based CBS Organization System to support the prediction and management of the total project cost, which is the most important part of construction project planning. To achieve this, CBS cost items for mega-projects were initially deduced, based on which a standard CBS was developed.

The developed CBS Organization System supports easy and rapid organization of a CBS that suits the properties of megaprojects by adding/deleting some cost items based on the standard CBS. The developed system is expected to enable CMrs or owners with insufficient experience to use the system effortlessly.
\end{abstract}

Keywords: Web-based, Cost Breakdown Structure (CBS), Mega-projects, Cost Prediction and Management

\section{INTRODUCTION}

Urban renewal projects are being actively initiated, with focus on declining urban regions for the creation of social profit and the revitalization of inactive cities. Most of these projects are being constructed at a mega-project scale, and many facilities, including residential, commercial, business, and cultural, are undergoing integrated development. Furthermore, large amounts of investments are being allocated for construction costs over a long period of time, with the participation of various stakeholders. These projects pose various problems, such as project delays, increased project costs, and conflicts between stockholders [9]. To solve these problems, a program-based approach is required to replace the existing management method based on a unit-project approach. Since there are few megaproject performance cases, difficulties are encountered in efficiently managing such projects. There is a special need to come up with an appropriate budget for total costs from the initial phase of the project, as this is the most important part of the project planning. There are many difficulties in establishing the budget at the initial phase of a project because of the lack of tools that support the prediction and management of total costs at the program level.

Thus, this study was aimed to develop a web-based CBS Organization System to support the prediction and management of total costs for the users and the owners, and simultaneously proposed the CBS cost items for megaprojects.

\section{LITERATURE REVIEW}

\subsection{Status of Mega-projects}

Mega-projects are very large investment projects. The U.S. Federal Highway Administration defines mega-projects as major infrastructure projects that cost more than US $\$ 1$ billion, or that project a significant cost that attracts a high level of public attention or political interest because of the substantial direct and indirect impacts on the community, environment, and budgets [5].

As described above, the definition of mega-projects as investments with a total cost of over US $\$ 1$ billion applies to most current mega-projects that are being planned or developed in Korea (i.e., Eunpyung New Town, AsanBaebang-Yongsan Transit, Cheonan Business Park 
Development Project, etc.). Sometimes, investments with a total cost that do not exceed US\$1 billion, such as the Incheon Woonbuk Combined Leisure Complex Development Project (670 million) and the Yongin Jukjeon Transit Development Project (520 million), are still referred to as mega-projects. Hyun et al. (2009) analyzed 19 mega-projects to define a mega-project as the investments with "a total cost of over 500 million that accommodates the form of facilities with more than three uses, together with a consistent plan based on a single master plan, as a combined project that is executed with organic connection with all its functions".

A mega-project is difficult to efficiently manage, since a large amount of cost is invested over a long period of time and various stakeholders participate in the project. Ha (2010) defined the problems of mega-projects as shown in Table 1.

Table 1 Problems of Mega-projects

\begin{tabular}{c|l}
\hline & - Conflicts between Participating Stakeholders \\
& - Increase in project cost and project delays \\
$\begin{array}{c}\text { Problems of } \\
\text { Mega- } \\
\text { Projects }\end{array}$ & - Mixed use of public- and civil-developed sections \\
& - Regulations and project process not established \\
& - Importance of performance management \\
\hline
\end{tabular}

\subsection{Cost Breakdown Structure}

Breaking down a complex problem into a set of subproblems is a common strategy for solving a complex and/or a new problem. It can make the complex problem easy to understand and solve [7]. Various studies related to CBS have been performed for the efficient management of construction costs. Blanchard and Fabrycky (1998) state that the CBS constitutes a functional breakdown of costs, and for the life cycle cost of a product, the entire life cycle could be considered and identified in the CBS. This includes the research and development cost, production and construction cost, operation and system support cost, and retirement and disposal cost. Lee et al. (2007) and Le et al. (2009) largely classified the CBS as the initial costs (i.e., the construction cost), O\&M costs (i.e., the repair cost), and disposal costs (i.e., the residual value) in the studies related to the Life Cycle Cost (LCC) analysis. Also, most studies on integration between project costs and schedule have come up with a CBS that considers only the cost invested in the construction phase ([10], [15], [4]). These studies intended to control the project progress in the construction phase through the integrated management of the cost and schedule.

Hyun et al. (2004) analyzed the Korean Architectural Standard Specifications of the Classification System, the Standards for Construction Quantity Estimation, the Actual Construction Cost Application Types and System, and the Classification of Standard Estimating Systems established by the Ministry of Land, Transport, and Maritime Affairs (MLTM) of Korea. They pointed out the difference between the standards of classification of the breakdown structure and that most CBSs are based on the type of work. The CBSs such as $\mathrm{Cl} / \mathrm{SfB}$ (Construction Indexing / Samarbetskommitten for Byggn-adsfragor), Uniclass (Unified Classification for the Construction Industry), Masterformat, Uniformat, and the ISO International Standard Construction Information Classification System are classified into factors and parts. Efforts have been made to combine the classification system by establishing a consistent classification standard for smooth communication in the construction process [8].

Table 2 Classification of Costs

\begin{tabular}{|c|c|c|c|}
\hline Researchers & Classification & Cost Items & Note \\
\hline $\begin{array}{l}\text { Blanchard } \\
\text { and } \\
\text { Fabrycky } \\
\text { (1998); } \\
\text { Lee et al. } \\
\text { (2007); } \\
\text { Le et al. } \\
\text { (2009) }\end{array}$ & $\begin{array}{c}\text { Life Cycle } \\
\text { Cost (LCC) }\end{array}$ & $\begin{array}{c}\text { Initial cost, Operation } \\
\text { and Maintenance cost, } \\
\text { Dissolution/Remaining } \\
\text { value, etc. }\end{array}$ & $\begin{array}{l}\text { The land cost, } \\
\text { design cost, } \\
\text { financing cost, } \\
\text { etc. are not } \\
\text { generally } \\
\text { included in } \\
\text { the early } \\
\text { investment } \\
\text { cost }\end{array}$ \\
\hline $\begin{array}{l}\text { Jung and } \\
\text { Woo } \\
\text { (2004); } \\
\text { Chen } \\
\text { (2008); } \\
\text { Cho et al. } \\
\text { (2010) }\end{array}$ & $\begin{array}{l}\text { Construction } \\
\text { cost }\end{array}$ & $\begin{array}{l}\text { Direct construction cost, } \\
\text { Indirect construction } \\
\text { cost, etc. }\end{array}$ & $\begin{array}{l}\text { Generally, } \\
\text { material cost, } \\
\text { labor cost, } \\
\text { equipment } \\
\text { cost, etc. are } \\
\text { included }\end{array}$ \\
\hline This study & Total cost & $\begin{array}{l}\text { Land cost, Construction } \\
\text { cost, Selling cost, } \\
\text { Financing cost, etc. }\end{array}$ & $\begin{array}{c}\text { All costs } \\
\text { invested until } \\
\text { the } \\
\text { completion of } \\
\text { the } \\
\text { construction }\end{array}$ \\
\hline
\end{tabular}


As verified in many aforementioned studies, the CBS is diversely classified according to the purpose and scope of the study, and the definition of 'cost' varies across studies. The CBS in this study includes all costs invested in a mega-project from the initial phase of the project to the completion phase of the project, and is composed of cost items for the management of the program (mega-project) level. The definitions of 'cost' in previous studies are summarized in Table 2.

\section{DEVELOPMENT OF THE CBS ORGANIZATION SYSTEM FOR MEGA-PROJECTS}

\subsection{Deduction of Cost Items}

As examined in Table 2, the 'cost' (defined as the 'total cost' in this study) that was used in this study refers to all costs invested from the initial phase of a project to completion of construction. Accordingly, existing literature related to the project feasibility analysis were analyzed to deduce the CBS cost items that compose the total cost. The results of the analysis showed the budget analysis items composed of approximately 20-70 detailed cost items, with the cost items at the first level such as the land cost, construction cost, selling cost, financial cost, and incidental cost as the standards ([11], [15], [16]). These studies, however, are the results of the analysis of single projects and specific projects, so they have limitations in terms of direct application to mega-projects. Accordingly, this study conducted an additional analysis by collecting budget analysis data from three ongoing mega-projects. Based on these data, interviews were conducted with two real estate development specialists and three CMrs who have more than ten years experience in this field. Finally, the cost items that must fundamentally be included in the CBS of mega-projects were defined as 48 items over the process of addition, deletion, and combination of the cost items. The specialists stated that cost items might be added or deleted based on the properties of the mega-project. Thus, it is important to establish flexible CBS cost items in the development of future systems.

\subsection{Standard CBS Construction}

Based on the 48 detailed cost items deduced in this study, a breakdown structure that is appropriate for mega-projects was constructed through revisions by specialists based on the classification system used in previous studies. The results are shown in Table 3.

Table 1 CBS Cost Items for Mega-Projects

\begin{tabular}{|c|c|c|c|}
\hline \multicolumn{4}{|c|}{ CBS Cost Items for Mega-projects } \\
\hline $\begin{array}{l}\text { Classification } \\
\text { (code) }\end{array}$ & $\begin{array}{c}\text { Level I } \\
\text { (code) }\end{array}$ & $\begin{array}{l}\text { Level II } \\
\text { (code) }\end{array}$ & $\begin{array}{l}\text { Level III } \\
\text { (code) }\end{array}$ \\
\hline \multirow{12}{*}{$\begin{array}{l}\text { Expenses } \\
\text { (E) }\end{array}$} & \multirow{3}{*}{$\begin{array}{l}\text { Land cost } \\
(\mathrm{E}-\mathrm{L})\end{array}$} & $\begin{array}{l}\text { Land } \\
\text { purchasing cost } \\
\text { (E-L01) }\end{array}$ & $\begin{array}{c}\text { Purchasing cost } \\
\text { (E-L0101) } \\
\text { Consulting expenses } \\
\text { (E-L0102) }\end{array}$ \\
\hline & & $\begin{array}{l}\text { Relocation cost } \\
\quad \text { (E-L02) }\end{array}$ & $\begin{array}{l}\text { Acquisition tax } \\
\text { (E-L0201) } \\
\text { Education tax } \\
\text { (E-L0202), etc. }\end{array}$ \\
\hline & & $\begin{array}{l}\text { Land } \\
\text { ownership cost } \\
\text { (E-L03) }\end{array}$ & $\begin{array}{l}\text { Property tax } \\
\text { (E-L0301) } \\
\text { City planning tax } \\
\text { (E-L0302), etc. }\end{array}$ \\
\hline & \multirow{3}{*}{$\begin{array}{l}\text { Construction } \\
\text { cost (E-C) }\end{array}$} & $\begin{array}{l}\text { Subcontract } \\
\text { construction } \\
\text { cost (E-C01) }\end{array}$ & $\begin{array}{c}\text { Direct construction cost } \\
\text { (E-C0101) } \\
\text { Indirect construction } \\
\text { cost } \\
\text { (E-C0102) }\end{array}$ \\
\hline & & $\begin{array}{l}\text { Outsourced } \\
\text { service cost (E- } \\
\text { C02) }\end{array}$ & $\begin{array}{l}\text { Planning cost } \\
\text { (E-C0201) } \\
\text { Supervision cost } \\
\text { (E-C0202), etc. }\end{array}$ \\
\hline & & $\begin{array}{l}\text { Other } \\
\text { construction } \\
\text { costs } \\
(\mathrm{E}-\mathrm{C} 03)\end{array}$ & $\begin{array}{c}\text { Demolition cost } \\
\text { (E-C0301) } \\
\text { Wiring construction cost } \\
\text { (E-C0302), etc. }\end{array}$ \\
\hline & \multirow{2}{*}{$\begin{array}{l}\text { Selling cost } \\
\text { (E-S) }\end{array}$} & $\begin{array}{l}\text { Model house- } \\
\text { related cost } \\
\text { (E-S01) }\end{array}$ & $\begin{array}{c}\text { Construction cost of } \\
\text { M/H } \\
\text { (E-S0101) } \\
\text { Site rent fee of M/H } \\
\text { (E-S0102), etc. }\end{array}$ \\
\hline & & $\begin{array}{l}\text { Parcel-related } \\
\text { cost (E-S02) }\end{array}$ & $\begin{array}{l}\text { Proxy parcel } \\
\text { commission } \\
\text { (E-S0201) } \\
\text { Advertising expenses } \\
\text { (E-S0202), etc. }\end{array}$ \\
\hline & $\begin{array}{l}\text { Financing } \\
\text { cost (E-F) }\end{array}$ & $\begin{array}{l}\text { PF cost } \\
\text { (E-F01) }\end{array}$ & $\begin{array}{l}\text { PF interest (E-F0101) } \\
\text { PF fee (E-F0102), etc. }\end{array}$ \\
\hline & \multirow{3}{*}{$\begin{array}{l}\text { Incidental } \\
\text { cost (E-I) }\end{array}$} & $\begin{array}{l}\text { Taxes and the } \\
\text { public utilities' } \\
\text { charge (E-I01) }\end{array}$ & $\begin{array}{l}\text { School site acquisition } \\
\text { charges (E-I0101), } \\
\text { Quasi-tax(E-I0102), etc. }\end{array}$ \\
\hline & & $\begin{array}{l}\text { Various } \\
\text { expenses } \\
\text { (E-I02) }\end{array}$ & $\begin{array}{l}\text { Contingency fee } \\
\text { (E-I0201), } \\
\text { AMC operation fee } \\
\text { (E-I0202), etc. }\end{array}$ \\
\hline & & $\begin{array}{l}\text { Other costs (E- } \\
\text { I03) }\end{array}$ & $\begin{array}{l}\text { Licensing expenses } \\
\text { (E-I0301), } \\
\text { Preservation registration } \\
\text { fee (E-I0302), etc. }\end{array}$ \\
\hline $\begin{array}{l}\text { Number of } \\
\text { elements }\end{array}$ & 5 & 13 & 48 \\
\hline
\end{tabular}


As shown in Table 3, CBS cost items for mega-projects are categorized into three levels. The first level of CBS cost items is composed of the following five cost items: the land cost, construction cost, selling cost, financial cost, and incidental cost. The lowest level, level 3, is composed of 48 elements, from the purchasing cost to the preservation registration fee. Since the CBS cost items can be varied according to the properties of the mega-project, this study established a standard CBS composed of the aforementioned 48 items to support the organization of a CBS that is appropriate for alternative mega-projects through the addition or deletion of some cost items based on the standard CBS.

\subsection{CBS Cost Code Setting}

This study assigned a distinct code for each cost item, for efficient management and distinction of the cost items. The standards for the assignment of codes to the cost items were based on the Construction Information Classification System of Korea. As all the cost items are expenses, they were given the symbol ' $\mathrm{E}$ ' (for expense). According to the properties of the cost items at each level, they were given symbols at level 1 , and numbers at levels 2 and 3. As the CBS in this study has few cost items, the levels 2 and 3 were set as two-digit numbers, with a maximum of 99 items. The code-setting standard at each level of the cost items are shown in Table 4.

Table 3 Code-Setting Standards for CBS Cost Items

\begin{tabular}{cccc}
\hline \multicolumn{4}{c}{ CBS Cost Items for Mega-projects } \\
\hline $\begin{array}{c}\text { Classification } \\
\text { (Symbol) }\end{array}$ & $\begin{array}{c}\text { Level I } \\
\text { (Symbol) }\end{array}$ & $\begin{array}{c}\text { Level II } \\
\text { (Number) }\end{array}$ & $\begin{array}{c}\text { Level III } \\
\text { (Number) }\end{array}$ \\
\hline & Land cost (L) & $01-99$ & $01-99$ \\
Expense (E) & Selling cost (S) & $01-99$ & $01-99$ \\
& Financing cost (F) & $01-99$ & $01-99$ \\
& Incidental cost (I) & $01-99$ & $01-99$ \\
& & & \\
\hline
\end{tabular}

As shown in Table 3, the first cost items at levels 1, 2, and 3 , namely the land cost, land purchasing cost, and land expenses, were given the codes 'E-L', 'E-L01', and 'EL0101', respectively. The coding system for the CBS cost items is shown in Figure 1.

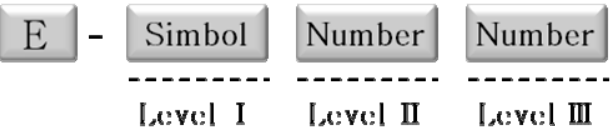

Fig. 1 Coding System for CBS Cost Items

\subsection{Development of the CBS Organization System}

Interface Management is the systematic control of all communications that support a process operation [2]. It has the aspect of usability with respect to the standard that judges the user interface (UI). Devising of the core of usability rapidly responds to the demand of the user according to the change in the web environment, and supports the rapid repetition of prototyping [12]. This study aimed to develop a CBS Organization System focused on usability, based on the standard CBS and codes, and the deduced cost items. The UIs of the developed system are shown in Figures 2-4.

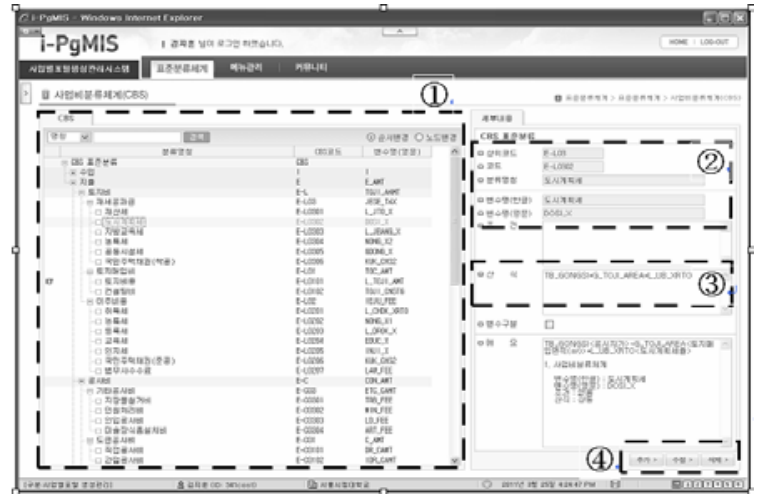

Fig. 2 Standard CBS-composing UI

The CBS Organization System supports easy and rapid organization of the CBS of a mega-project through the standard CBS. As shown in Figure 2, the 48 deduced cost items take the form of a tree (refer to (1) in Figure 2), and the detailed information on each cost item is listed on the right side of Figure 2. In (2) in Figure 2, the name of variables, codes, and priority code are shown; and (3) in Figure 2 defines the formula for calculating the value of 
the each cost item. These formulas are used to predict the total project cost at the initial phase of the project. Furthermore, the Edit/Add/Delete button (refer to (4) in Figure 2) at the bottom right allows the user to freely change the standard CBS cost items.

Figure 3 displays the organization of the CBS (refer to (6) in Figure 3) for a mega-project through the standard CBS (refer to (5) in Figure 3). The user can copy the cost item selected on the left standard column and copy it on the right column with a single click (refer to (7) in Figure 3).

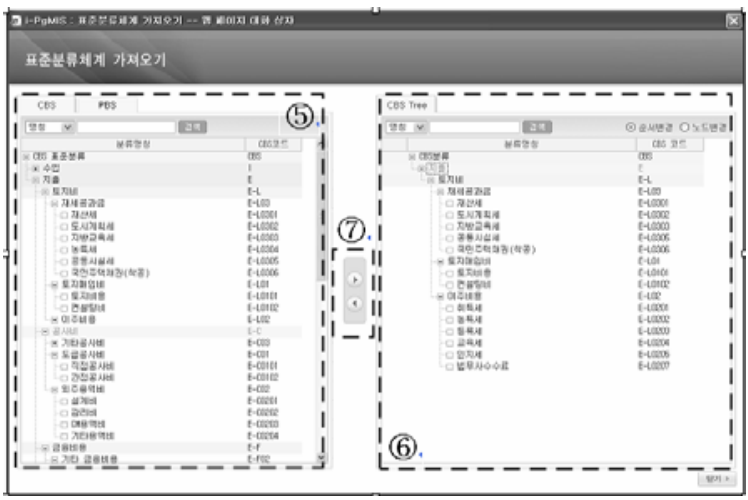

Fig. 3 UI that uses the standard CBS

Figure 4 shows the UI that displays the results of Figure 3. If the cost items must be changed due to the distinct characteristics of a mega-project, the user can directly edit/add/delete (refer to (8) in Figure 4) the cost items on this screen, and enter the detailed information (refer to 9) in Figure 4).

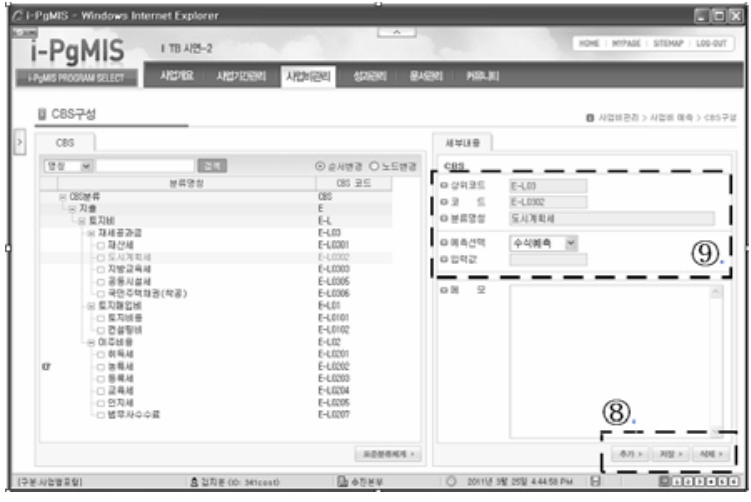

Fig. 4 UI that constructs the CBS of the mega-project

\subsection{Examination of the Availability of Use}

This study examined the usability and suitability of standard CBS cost items to verify the availability of the developed system. First, the usability was examined by two CMrs with more than 10 years of experience, through their personal use of the developed system and their expression of their opinions on the system. Very good reviews were received on the usability of the product. First, the subjects stated that a CBS of a mega-project could be rapidly organized due to the provision of the standard CBS. Second, they stated that the standard CBS could become guidelines for owners or CMrs with insufficient experience. Moreover, to examine the suitability of the standard CBS cost items, this study comparatively analyzed them with the budget analysis cost items of an ongoing mega-project. The results showed 44 among the 51 budget analysis cost items of the case project are included in the standard CBS cost items. Four (48-44) cost items among the 48 cost items of the standard CBS were excluded from the case project, since such cost items were among the other cost items to be reflected in the total project cost (i.e., the 'public grievance processing cost' is included in the 'contingency fee' to be reflected in the total cost). Furthermore, the seven (51-44) cost items that were not included in the standard CBS were verified to be limited to the mega-project, such as the cultural asset survey fee, contributed acceptance construction cost, sales compensation cost, and costs related to the substitutive sales site. Accordingly, such cases can be easily resolved using the cost item edit/add/delete function, as explained in Figure 4.

\section{CONCLUSION}

This study aimed to develop a web-based CBS Organization System that can support the prediction of a total cost at the initial phase of a mega-project, and efficient management of the project costs, which is the most important part of planning a construction project. To achieve this, previous studies and ongoing mega-project cases were first analyzed to deduce 48 cost items that must fundamentally be included in the CBS. A breakdown 
structure and codes were established that were directly based on the deduced cost items to organize a standard CBS for the mega-projects. The usability and suitability of the standard CBS cost items were examined to verify the availability of the developed system. First, good reviews were received from specialists on the usability of the product, due to its easy and rapid organization of the CBS. The usability of the standard CBS cost items showed an accuracy of $91.7 \%$ (44/48*100\%).

The web-based CBS Organization System developed in this study enables easy and rapid composition of the CBS of a mega-project, and can also serve as guidelines for owners and CMrs with insufficient experience. For further research, a standard CBS that is suitable for many cases must be developed through additional case studies, and more accurate formula for each CBS cost item must be established for predicting the total cost of mega-projects.

\section{ACKNOWLEDGEMENT}

This research was supported by a grant (07 Urban Renaissance B03) from High-Tech Urban Development Program funded by the Ministry of Land, Transport and Maritime Affairs of the Korean Government.

\section{REFERENCES}

[1] Blanchard, B. S., and Fabrycky, W. J., Systems Engineering and Analysis, $3^{\text {rd }}$ ed., Prentice-Hall, Inc. 1998.

[2] CCPS, Interface Management: Effective Communication to Improve Process Safety, CCPS Safety Alert, 2004.

[3] Chen, P. H., "Integration of cost and schedule using extensive matrix method and spreadsheets", Automation in Construction, Vol. 18(1), pp. 32-41, 2008.

[4] Cho, K. M., Hong, T. H., and Hyun, C. T., “Integrated Schedule and Cost Model for Repetitive Construction Improve Process Safety, CCPS Safety Alert, 2004. Process”, J. Manage. Eng., ASCE, Vol. 26(2), pp. 78-88, 2010.

[5] Flyvbjerg, B., Bruzelius, N., and Rothengather, W., Megaprojects and Risk; an Anatomy of Ambition, Cambridge University Press, Cambridge, UK, 2003.
[6] Ha, S. R., Accomplishment of Pre-Workshop Phase for the Application of VE at Planning Stage of Mega-Project, MS Thesis, University of Seoul, Seoul, Korea, 2010.

[7] Huang, G. R., Cost Modeling Based on Support Vector Regression for Complex Products during the Early Design Phase, PhD Dissertation, Virginia Polytechnic Institute and State University, 2007.

[8] Hyun, C. T., Hong, T. H., Koo, K. J., Yeon, H. J., Moon, H. S., and Cho, K. M., "Development of the Space Cost Breakdown Structure(CBS) for Multi-Family Housing Projects”, Korea Institute of Cons. Eng. and Manage., Vol. 8(6), pp. 178-187, 2007.

[9] Hyun, C. T., Hong, T. H., Son, M. J., Lee, H. C., and Ha, S. R., "Development of the Cost Break Structure Organization Tool for Planning Phase of Mixed Used Development Project”, Architectural Institute of Korea, Vol. 25(8), pp. 185-194, 2009.

[10] Jung, Y. S., and Woo, S. K., "Flexible Work Breakdown Structure for Integrated Cost and Schedule Control”, J. Constr. Eng. Manage., ASCE, Vol. 130(5), pp. 616-625, 2004.

[11] Kim, G. H., and Song, S. J., "Study of Feasibility Analysis of Apartment Project focused on Characteristics of Planning under influence of redemption”, Korea Planners Association, Vol. 40(3), pp. 47-66, 2005.

[12] Knight, A., and Dai, N., “Objects and the Web”, IEEE Software, Vol. 19(2), pp. 51-59, 2002.

[13] Le, Y., Ren, J. S., Ning, Y., He, Q. H., and Li, Y. K., "Life Cycle Cost Integrative Management in Construction Engineering”, ICISE-2009, pp. 4367-4370, 2009.

[14] Lee, D. H., Kim, K. T., Kim, H. B., Jun, J. T., and Han, C. H., "A Study on the Life Cycle Cost Analysis in Light Rail Transit Bridges: Focused on Superstructure”, Korea Institute of Cons. Eng. and Manage., Vol. 2(200703), pp. 1-11, 2007.

[15] Shin, W. S., and Park, K. J., “A Study on the Model for a Feasibility Study of an Apartment Project”, Architectural Institute of Korea, Vol. 21(3), pp. 153-160, 2005.

[16] Yun, S. H., “A case study of feasibility analysis and decision making method for the construction project development”, Architectural Institute of Korea, Vol. 19(10), pp. 75-82, 2003. 